\title{
Allopregnanolone reduces neuroendocrine response to acute stressful stimuli in sheep
}

\author{
Tomasz Misztal, Patrycja Młotkowska, Elżbieta Marciniak and Anna Misztal \\ Department of Animal Physiology, The Kielanowski Institute of Animal Physiology and Nutrition, Polish Academy of Sciences, Jabłonna, Poland \\ Correspondence should be addressed to T Misztal: t.misztal@ifzz.pl
}

\begin{abstract}
The verified hypothesis assumed that centrally administered neurosteroid, allopregnanolone (AL), could affect basal and/or stress-induced activity of the hypothalamic-pituitary-adrenal (HPA) axis in sheep. Four groups ( $n=6$ each) of luteal-phase sheep were intracerebroventricularly infused for 3 days with a vehicle without stress (control); a vehicle treated with stressful stimuli (isolation and partial movement restriction) on the third day; $\mathrm{AL}(4 \times 15 \mu \mathrm{g} / 60 \mu \mathrm{L} / 30 \mathrm{~min}$, at 30-min intervals) treated with stressful stimuli, and AL alone. Simultaneously, the push-pull perfusion of the infundibular nucleus/median eminence and plasma sample collection were performed. After the experiment, the sheep were killed to collect the hypothalamic and anterior pituitary (AP) tissues. Stressful stimuli evoked an increase in the expression of corticotropin-releasing hormone $(\mathrm{CRH})$ and arginine vasopressin (AVP) mRNA in the hypothalamic paraventricular nucleus (PVN), and AVP receptor (V1b) and proopiomelanocortin (POMC) mRNA in the AP; the concentrations of perfusate $\mathrm{CRH}$, and plasma adrenocorticotropic hormone (ACTH) and cortisol compared to controls. Conversely, the expression of the $\mathrm{CRH}$ receptor (CRHR1) mRNA in the AP was downregulated. AL decreased the expression of CRH and AVP MRNA in the PVN, and AVPRV1b and POMC mRNA in the AP in stressed sheep, compared to only stressed ones. There was also a reduction in perfusate $\mathrm{CRH}$, and plasma $\mathrm{ACTH}$ and cortisol concentrations. AL alone decreased the expression of CRHR1 mRNA in the AP, and plasma cortisol concentration at the beginning of the collection period compared to controls. In conclusion, AL may function centrally as a suppressor of HPA axis activity in stressed sheep.
\end{abstract}

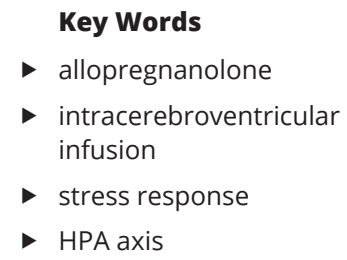

Journal of Endocrinology (2020) 244, 201-211

\section{Introduction}

The neuroendocrine response of the hypothalamicpituitary-adrenal (HPA) axis to stress allows the animal to adapt to adverse conditions, restoring physiological homeostasis (McEwen 2007). Conversely, prolonged exposure to stressful stimuli may cause pathological changes in the organism (Vyas et al. 2016). The main central neurohormones that initiate a stress response include corticotropin-releasing hormone (CRH) and arginine vasopressin (AVP), which are synthetized primarily in the hypothalamic paraventricular nucleus $(\mathrm{PVN})$. Both neuropeptides are involved in the regulation of adrenocorticotropic hormone (ACTH) secretion from the anterior pituitary (AP). The actions of CRH and AVP in the AP corticotrophs are mediated by specific $G$ protein-coupled receptors: CRHR1 and V1b respectively (Nikodemova et al. 2002, Jasnic et al. 2013). ACTH then 
stimulates the adrenal glands to synthesize and release glucocorticoids (GCs) and mineralocorticoids, which may act at multiple targets in the body to facilitate the necessary metabolic and behavioral adaptations (McEwen 2007). In addition, GCs provide negative feedback control of the HPA axis at the central and pituitary levels, terminating the stress response. Moreover, the activity of $\mathrm{CRH}$ neurons in the PVN is tightly regulated by inhibitory $\gamma$-aminobutyric acid (GABA)ergic synaptic input (Decavel \& Van den Pol 1990, Herman et al. 2004) that, to a large extent, originates in adjacent interneuron populations (Boudaba et al. 1996). Recent studies have shown that GCs may also influence the GABAergic control of CRH neurons by the upregulation of $\mathrm{GABA}_{\mathrm{A}}$ receptors (Colmers $\&$ Bains 2018).

In the mammalian brain, several neuroendocrine factors are formed that are able to reduce the stress response in itself or limit its negative effects. Their action is particularly important in a situation of acute stress, as well as during pregnancy and lactation, protecting the fetus or newborn from excess GC (Brunton 2016, Hasiec \& Misztal 2018). The results of previous studies on rodents indicated a specific role of brain-synthesized steroids, which are a component of the mechanism that allows stress coping (McEwen 2007). Synthesis of these compounds occurs in numerous glial and nerve cells of the central nervous system (CNS) through conversion of blood-derived precursors or de novo from cholesterol (Baulieu 1991, Paul \& Purdy 1992). The most recognized neurosteroid is allopregnanolone (AL), a product of progesterone conversion by $5 \alpha$-reductase and 3 $\alpha$-hydroxysteroid dehydrogenase (Melcangi et al. 1993). The results of previous studies on rats and mice have indicated the inhibitory properties of AL in relation to the HPA axis (Brunton et al. 2009, Gunn et al. 2013). These are reached by potent neurosteroid binding to membrane-bound $\mathrm{GABA}_{\mathrm{A}}$ receptors, where they enhance GABA-mediated inhibitory action on PVN neurons (Sarkar et al. 2011). Moreover, AL activated and maintained endogenous opioid inhibition of HPA axis responses to stress in late-pregnant rats (Brunton et al. 2009).

Studies on AL function in adult farm animals are rare, although they could have a great impact on humans. Some studies performed on sheep focused mainly on the role of this compound in the developing brain of the fetus and neonate. In general, it was shown that neuroactive steroids had potent suppressive effects on the CNS of fetal sheep (Nicol et al. 1999). The results of another study indicated that AL modulated the constitutive rate of apoptosis and proliferation in the hippocampus and cerebellum of the fetal brain (Yawno et al. 2009). It was also found that stress evoked by the lipopolysaccharide administration induced an increase in AL concentration in the newborn brain, which subsequently contributed to somnolence (Billiards et al. 2002). In the present study, which belongs to the field of research on the effects and prevention of stress, we verified the hypothesis that a centrally administered AL could affect basal and/or stressinduced activity of the HPA axis in sheep. As sheep are herd animals, a few hours of isolation from the herd in combination with partial restriction of movement were used as the acute stress stimuli (Hasiec et al. 2014).

\section{Materials and methods}

\section{Animal management}

All animal procedures were conducted in accordance with the Polish Act on the Protection of Animals Used for Scientific or Educational Purposes (2015) and were approved by the 2nd Local Ethics Committee for Animal Experiments, Warsaw University of Life Sciences - SGGW, Warsaw, Poland (Resolution No. WAW2-24/2016). Twenty-four Polish Longwool sheep (a breed representing reproduction seasonality), aged 2 years and weighing $55 \pm 3 \mathrm{~kg}$ were used in the experiment. They were farmed at the Sheep Breeding Center of the Kielanowski Institute of Animal Physiology and Nutrition, Polish Academy of Sciences. Throughout the experiment they were kept indoors in individual pens under natural lighting conditions $\left(52^{\circ} \mathrm{N}, 21^{\circ} \mathrm{E}\right)$. The animals were fed twice a day with a diet based on pelleted concentrate according to the recommendations of the National Research Institute of Animal Production (Krakow-Balice, Poland) - National Institute for Agricultural Research (France) (Strzetelski 2009). All sheep had free access to hay, water and mineral licks.

\section{Brain surgery}

Sheep were bilaterally implanted with two stainless steel guide cannulae: one into the infundibular nucleus/median eminence (IN/ME), (outer diameter $1.6 \mathrm{~mm}$, positions: frontal $29.5-30.5 \mathrm{~mm}$ and sagittal $1.0 \mathrm{~mm}$ ) and the second into the third brain ventricle (IIIv), (outer diameter $1.2 \mathrm{~mm}$, positions: frontal $30.5-31.5 \mathrm{~mm}$ and sagittal $1.0 \mathrm{~mm}$ ), in accordance with the stereotaxic coordinate system for the sheep hypothalamus (Welento et al. 1969). The implantation was performed under general anesthesia 
(xylazine: $40 \mathrm{mg} / \mathrm{kg}$ of body mass, intravenously; xylapan and ketamine: $10-20 \mathrm{mg} / \mathrm{kg}$ of body mass, intravenously; Bioketan, Vetoquinol Biowet, Pulawy, Poland) through a hole drilled in the skull, in accordance with the procedure described by Traczyk \& Przekop (1963). Guide cannulae were fixed to the skull with stainless steel screws and dental cement. The external opening of the canal was closed with a stainless steel cap. After the surgery, ewes were injected daily with antibiotics for 5 days ( $1 \mathrm{~g}$ streptomycin and 1,200,000 IU benzylpenicillin; Polfa, Warsaw, Poland) and with analgesics for 4 days (metamizole sodium 50 mg/animal; Biovetalgin, Biowet Drwalew, Drwalew, Poland, or meloxicam $1.5 \mathrm{mg} / \mathrm{animal}$; Metacam, Boehringer Ingelheim, Ingelheim am Rhein, Germany). Placement of the cannulae into the IIIv was confirmed by the outflow of CSF during surgery, and placement into the IN/ME was confirmed after slaughtering. The sheep used in the present study had the correctly localized cannulae.

\section{Drug preparation}

A day before infusion, AL (Sigma-Aldrich) was dissolved in a mixture (1:1) of DMSO (Blirt, DNA-Gdańsk, Gdańsk, Poland) and 20\% 2-hydroxypropyl- $\beta$-cyclodextrin (Sigma-Aldrich). After $24 \mathrm{~h}$, the mixture was diluted in a Ringer-Locke (RL) solution and divided into portions for individual sheep. The mixture without AL was diluted in RL and used as a control vehicle. Each portion of the infusion mixture contained $\%$ DMSO.

\section{Experimental design}

The experiment was conducted from mid-October to mid-December, during the reproductive season. Estrus synchronization was performed using the Chronogest-CR method. More specifically, polyester polyurethane sponges containing $20 \mathrm{mg}$ flugestone acetate (Intervet, Boxmeer, The Netherlands) were inserted in the sheep intravaginally for 14 days and then removed at the time of the pregnant mare's serum gonadotropin (PMSG) injection (500 i.u., Folligon, Intervet). Estrus occurred within 24-36 h of PMSG administration, and its duration was additionally controlled using a teaser ram. The sheep were randomly divided into four groups ( $n=6$ each) and all treatments were conducted over three consecutive days of the late luteal phase (days 12-14) of the estrous cycle. The treatments were as follows: 1 ) intracerebroventricular (i.c.v.) infusion of a vehicle for 3 days (C group); 2) i.c.v. infusion of a vehicle and use of stressful stimuli in the 3rd day (CS group); 3) i.c.v. infusion of AL and use of stressful stimuli in the 3rd day (AS group); and, 4) i.c.v. infusion of AL alone for 3 days (A group). All infusions were performed in a series of four 30-min infusions, at 30-min intervals (from 10:00 to 14:00 h). The dose of AL, $4 \times 15 \mu \mathrm{g} / 60 \mu \mathrm{L} / 30$ $\mathrm{min} /$ day was selected on the basis of our preliminary study (unpublished data, Grant No. 2015/19/B/NZ9/03706). A BAS Bee microinjection pump (Bioanalytical Systems, West Lafayette, IN, USA) and calibrated 1.0-mL gas-tight syringes were used. Stressful stimuli included isolation from other sheep and partial movement restriction in the experimental cage (protection against escaping from the cage). The duration of stressful stimuli covered the period of infusions $(4 \mathrm{~h})$.

Simultaneously, the IN/ME was perfused with RingerLocke solution using the push-pull method with a rate of flow of $10 \mu \mathrm{L} / \mathrm{min}$. The total perfusion time was $5 \mathrm{~h}$ including $1 \mathrm{~h}$ preperfusion (from 09:00 to 10:00 h) to eliminate $\mathrm{CRH}$ release artifacts caused by the insertion of the cannula. The proper 4-h long perfusion (from 10:00 to $14: 00 \mathrm{~h}$ ) allowed the gathering of eight perfusates (every $30 \mathrm{~min}$ ). Each $300 \mu \mathrm{L}$ perfusate was collected in a separate tube, which contained $30 \mu \mathrm{L}$ aprotinin (5-10 TIU per $\mathrm{mL}$, Sigma-Aldrich) to prevent peptide degradation. Immediately after the tubes were filled, they were frozen in liquid nitrogen and kept at $-80^{\circ} \mathrm{C}$ until the $\mathrm{CRH}$ concentration was assayed. All perfusions were executed with the CMA 402 pump (CMA, Stockholm, Sweden). The combination of two experimental techniques: the i.c.v. infusion and push-pull perfusion of the IN/ME, allows to observe direct changes in the secretory activity of the hypothalamic-pituitary axis that occur as a result of the central administration of the test substance (Hasiec et al. 2014). During the treatments, sheep were kept in comfortable experimental cages, where they could lie down and to which they were previously adapted.

\section{Blood sample and brain tissue collection}

Blood samples were collected during the 4-h long period (from 10:00 to $14: 00 \mathrm{~h}$ ) through a catheter that was inserted into the jugular vein a day before collection. Five milliliters of blood were taken every $10 \mathrm{~min}$ (total 125 $\mathrm{mL}$ ) and immediately divided into two portions: one with heparin $(30 \mu \mathrm{L}, 500$ units/mL; Polfa) to measure cortisol concentration and the other with EDTA $(100 \mu \mathrm{L}, 0.5 \mathrm{M}$, Sigma-Aldrich) to measure ACTH concentration. After centrifugation, the plasma was stored at $-20^{\circ} \mathrm{C}$ until the hormones were assayed.

Immediately after the experiment, sheep were slaughtered and the brains, along with pituitaries, 
were rapidly removed from the skull. After separation of the ME, each brain was sectioned sagittally into the cerebral hemispheres. The isolated blocks of the hypothalamus (cutting to a depth of $2 \mathrm{~mm}$ ) were dissected into three parts: preoptic area, anterior hypothalamus (AHA) and mediobasal hypothalamus (Ciechanowska et al. 2009), according to the stereotaxic atlas of the ovine brain (Welento et al. 1969). Landmarks included the optic chiasm, thalamus and mammillary body. Subsequently, the PVN was isolated from the AHA by point cut-out to a depth of 1-1.5 $\mathrm{mm}$. In addition, tissue of the anterior pituitary (AP) was collected. All tissue cuts were performed on sterile glass plates placed on ice, and the collected structures were frozen immediately in liquid nitrogen and then stored at $-80^{\circ} \mathrm{C}$.

\section{Relative abundance of mRNA analysis}

Total RNA from the hypothalamic and AP tissues was isolated using the NucleoSpin RNA II kit (MachereyNagel, Düren, Germany) $4 \times 4500$, according to the manufacturer's protocol. The concentration and purity of isolated RNA were quantified using a NanoDrop ND-1000 spectrophotometer (Thermo Fisher Scientific). RNA integrity was electrophoretically verified using 1.5\% agarose gel stained with ethidium bromide. cDNA was synthesized using the TranScriba Kit (A\&A Biotechnology, Gdynia, Poland) $10 \times 1000$ according to the manufacturer's instructions. For this synthesis, $1 \mu \mathrm{g}$ of total RNA was used in a reaction volume of $20 \mu \mathrm{L}$.

Quantitative polymerase chain reaction (qPCR) was performed with $5 \times$ HOT FIREPol ${ }^{\circledR}$ EvaGreen qPCR Mix Plus (Solis BioDyne, Tartu, Estonia). The PCR amplification mix contained $2 \mu \mathrm{L}$ cDNA template, $1 \mu \mathrm{L}$ primers $(0.5 \mu \mathrm{L}$ each, concentration of $10 \mathrm{pmol} / \mathrm{mL})$, $3 \mu \mathrm{L}$ buffer PCR Master Mix and $9 \mu \mathrm{L}$ dd $\mathrm{H}_{2} \mathrm{O}$. Reaction conditions were as follows: initial denaturation at $95^{\circ} \mathrm{C}$ for $15 \mathrm{~min}$, denaturation at $95^{\circ} \mathrm{C}$ for $15 \mathrm{~s}$, annealing at $60^{\circ} \mathrm{C}$ for $20 \mathrm{~s}$, and elongation at $72^{\circ} \mathrm{C}$ for $20 \mathrm{~s}$ (40 cycles). Specific primers for determining the expression of genes of interest (CRH and AVP in the PVN and CRHR1, AVPRV1b and $P O M C$ in the AP), as well as endogenous control genes (glyceraldehyde-3-phosphate dehydrogenase (GAPDH), and peptidylprolyl isomerase $\mathrm{C}$ (PPIC)) were designed using Primer3 software (The Whitehead Institute, Boston, MA, USA). Respective sequences of the primers are listed in Table 1. In order to confirm that single amplification products were amplified, the samples were stained with ethidium bromide and subjected to electrophoresis on an agarose gel before visualization under a UV light camera.

Data were analyzed with the Rotor Gene 6000 v. 1.7 software (Qiagen) using the comparative quantification option and determined using the Relative Expression Software Tool (2008) according to Pfaffl et al. (2002), based on a PCR efficiency correction algorithm developed by Pfaffl et al. (2004). The levels of gene expression were normalized using the geometrical means of two reference gene expressions GAPDH and PPIC. Both endogenous control genes were assayed in each sample to compensate for cDNA concentration variation and PCR efficiency between individual tubes.

\section{Hormone concentration assay}

The CRH concentration in the CSF was determined using a commercial ELISA kit CSB-EL005963SH

Table 1 Sequences of specific primers.

\begin{tabular}{|c|c|c|c|}
\hline Gene & Primers $\left(5^{\prime}-3^{\prime}\right)$ & GenBank Acc. No. & Amplicon size \\
\hline $\mathrm{CRH}$ & $\begin{array}{l}\text { F: CAGAAGCACCTCAGAAGCGC } \\
\text { R: GCGGCTGGAAGAAACTCAGG }\end{array}$ & XM_015097787.1 & 176 \\
\hline$A V P$ & $\begin{array}{l}\text { F: TCCGACCTGGAGCTGAGA } \\
\text { R: GGCAGGTAGATCTCCTCTTGG }\end{array}$ & NM_001126341.1 & 146 \\
\hline CRHR1 & $\begin{array}{l}\text { F: AATGAGAAGTGCTGGTTTGGC } \\
\text { R: GGTCATGAGGATGCGAACGA }\end{array}$ & NM_001009727.1 & 126 \\
\hline AVPR1B & $\begin{array}{l}\text { F: GACATAGTCAGCGACGGGAG } \\
\text { R: GGAGTGAGATAGACGGCAGC }\end{array}$ & NM_001246237.1 & 138 \\
\hline POMC & $\begin{array}{l}\text { F: GTAACCTGCTGGCGTGCAT } \\
\text { R: GAAGCTGCTGCTACCATTCC }\end{array}$ & NM_001009266.1 & 167 \\
\hline PPIC & $\begin{array}{l}\text { R: TGGAAAAGTCGTGCCCAAGA } \\
\text { R: TGCTTATACCACCAGTGCCA }\end{array}$ & XM_004008676.1 & 158 \\
\hline GAPDH & $\begin{array}{l}\text { F: GGGTCATCATCTCTGCACCT } \\
\text { R: GGTCATAAGTCCCTCCACGA }\end{array}$ & NM_001190390.1 & 131 \\
\hline
\end{tabular}

The real-time PCR amplification efficiencies of target and reference genes was 96-101\%.

AVP, arginine vasopressin; AVPR1B, AVP receptor 1B; CRH, corticotropin-releasing hormone; CRHR1, CRH receptor 1; F, forward primer; GAPDH, glyceraldehyde-3-phosphate dehydrogenase; POMC, proopiomelanocortin; PPIC, peptidylprolyl isomerase C (cyclophilin C); R, reverse primer.

https://joe.bioscientifica.com https://doi.org/10.1530/JOE-19-0376 (c) 2020 Society for Endocrinology Published by Bioscientifica Ltd. Printed in Great Britain 
(Cusabio, Wuhan, China) according to the manufacturer's protocol. The minimum detectable dose of CRH was less than $14 \mathrm{pg} / \mathrm{mL}$, and the intra- and inter-assay coefficients of variation (CVs) were $<15$ and $<15 \%$ respectively.

The plasma ACTH concentration was determined using a commercial ELISA kit CSB-EQ027618SH (Cusabio) according to the manufacturer's protocol. The minimum detectable dose of ACTH was less than $1 \mathrm{pg} / \mathrm{mL}$, and the intra- and inter-assay CVs were $<8$ and $<10 \%$ respectively.

The plasma cortisol concentration was measured using a radioimmunoassay (RIA), according to Kokot \& Stupnicki (1985), using rabbit anti-cortisol antisera (R/75) and a cortisol standard (Sigma-Aldrich). The assay sensitivity was $0.95 \mathrm{ng} / \mathrm{mL}$, and the intra- and inter-assay CVs were $<10$ and $<12 \%$ respectively.

\section{Statistical analysis}

Initially, all data were tested for normality by the ShapiroWilk normality test and then grouped into parametric and non-parametric. Perfusate CRH, as well as plasma ACTH and cortisol concentrations over time were analyzed using one-way ANOVA (STATISTICA, Stat Soft, Tulsa, OK, USA) or, where appropriate (hourly estimation), by the two-way ANOVA with repeated measures, with time and treatment as factors of repeated measurements. Each analysis was followed by the post hoc least significant difference test. $\mathrm{CRH}$ data from the preperfusion period were not included in the statistical analysis.

Statistical evaluations of differences in CRH and AVP mRNA expression in the PVN, as well as in CRHR1, AVPRV1b and POMC mRNA expression in the AP between treatment groups were carried out using non-parametric statistics: the Kruskal-Wallis test, followed by multiple comparisons of average ranks and then the MannWhitney $U$ test for particular groups. Differences were considered significant at $P<0.05$ and all data are presented as a mean \pm S.E.M.

\section{Results}

\section{Relative abundances of MRNA in the hypothalamus and AP tissues}

The relative abundances of both CRH and AVP mRNA in the PVN were compared between control and treatment groups (Fig. 1). The abundance of $C R H$ gene transcripts increased $(P<0.01)$ in the CS group, compared to the control group. Likewise, the content of $A V P$ gene transcripts
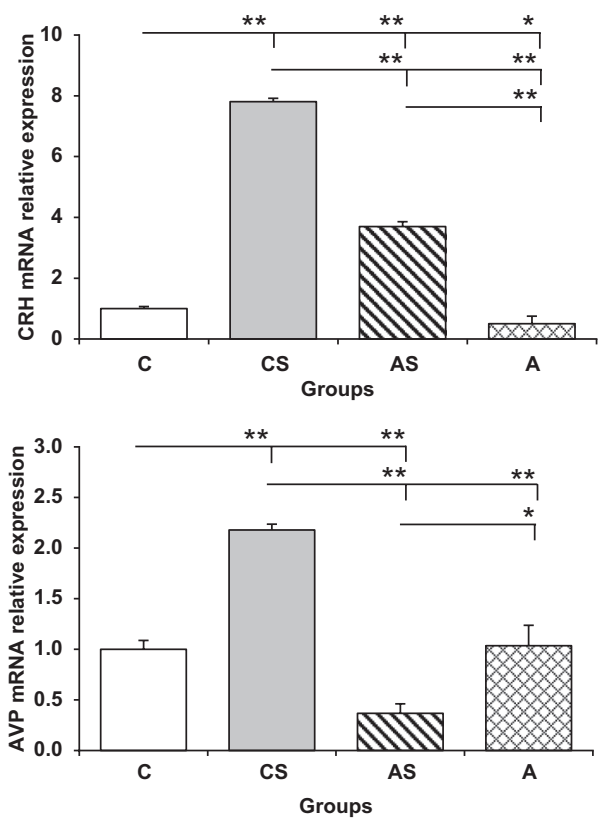

Figure 1

Relative mRNA expression (mean \pm S.E.M.) of corticotropin-releasing hormone ( $\mathrm{CRH}$, top) and arginine vasopressin (AVP, bottom) in the hypothalamic paraventricular nucleus of sheep treated with: vehicle (C), vehicle and stressful stimuli (CS), allopregnanolone and stressful stimuli (AS) and allopregnanolone alone (A). Significance of differences: $\star P<0.05, * * P<0.01$

was higher $(P<0.01)$ in the CS group than in controls. In the AS group, there was a reduction in abundance of both the CRH $(P<0.01)$ and AVP $(P<0.01)$ transcripts in comparison with the CS group. Interestingly, the relative abundance of CRH mRNA in the AS group was higher $(P<0.01)$, whereas that of AVP mRNA was lower $(P<0.01)$, compared to controls. AL infused alone caused a decrease in the relative abundance of CRH mRNA in the PVN, compared to controls $(P<0.05)$ and had no effect on AVP mRNA content. This latter, however, was less compared to the CS group $(P<0.01)$ and higher compared to the AS group $(P<0.05)$.

The relative abundances of CRHR1, AVPRV1b and POMC mRNA in the AP of sheep from all treatment groups are shown in Fig. 2. A decrease $(P<0.01)$ was observed in the abundance of CRHR1 mRNA in the CS, AS and A groups, compared to controls. On the contrary, the expression of AVPRV1b mRNA increased $(P<0.01)$ in response to stressful stimuli. In the AS group, there was reduction in the abundance of AVPRV1b mRNA $(P<0.01)$, in comparison with the CS group, while AL alone was without effect, compared to controls.

The relative abundance of POMC mRNA in the AP increased $(P<0.05)$ in response to stressful stimuli 

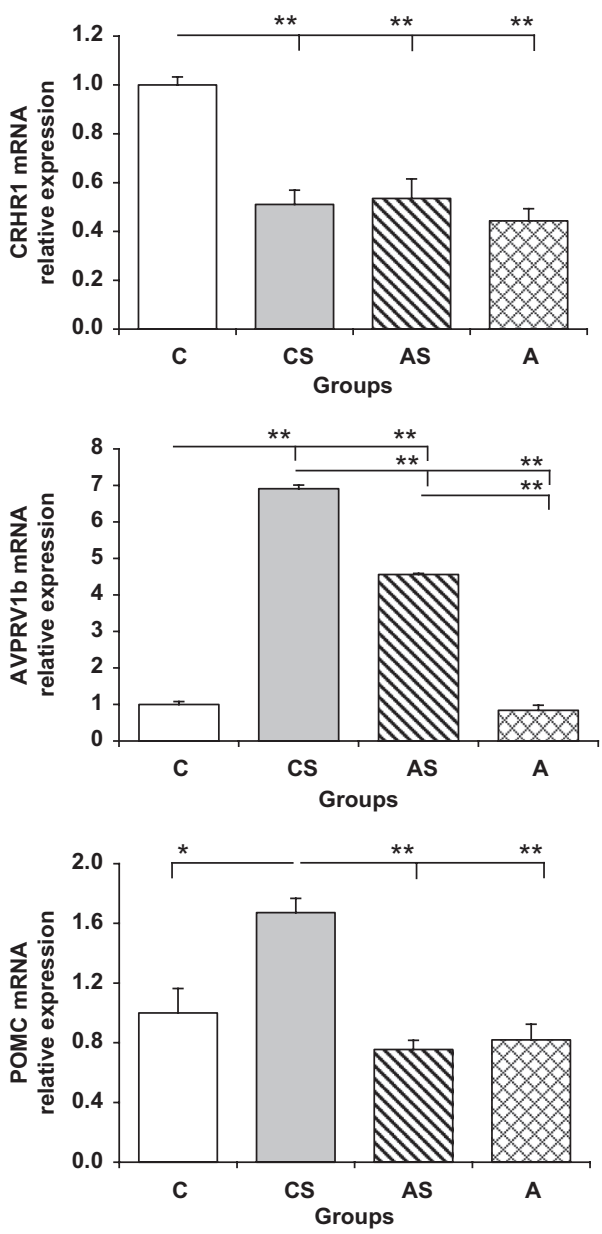

\section{Figure 2}

Relative mRNA expression (mean \pm S.E.M.) of corticotropin-releasing hormone receptor 1 (CRHR1, top), arginine vasopressin receptor V1b (AVPRV1b, middle) and proopiomelanocortin (POMC, bottom) in the anterior pituitary of sheep treated with: vehicle (C), vehicle and stressful stimuli (CS), allopregnanolone and stressful stimuli (AS) and allopregnanolone alone (A). Significance of differences: $* P<0.05$, $\star * P<0.01$.

(CS group), compared to controls. In the AS group, there was reduction in the abundance of $P O M C$ gene transcripts in comparison with the CS group $(P<0.01)$, reaching a level similar to controls. The abundance of POMC mRNA in the A group was also less than in the CS group $(P<0.01)$ but similar to those observed in the $\mathrm{C}$ and AS groups.

\section{Hormone concentration}

The mean perfusate CRH concentrations in sheep from all groups are shown in Fig. 3 and profiles of changes in mean $\mathrm{CRH}$ concentrations in consecutive perfusates during the collection period are shown in Fig. 4. Mean CRH concentration in the CS group was higher $(P<0.001)$ than in the control (non-stressed) group. The increased $\mathrm{CRH}$

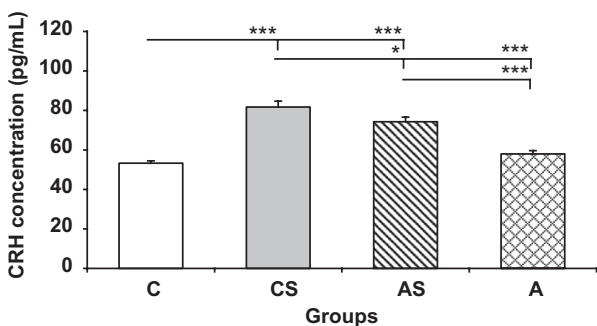

Figure 3

Perfusate corticotropin-releasing hormone $(\mathrm{CRH})$ concentrations (mean \pm S.E.M.) in sheep treated with: vehicle (C), vehicle and stressful stimuli (CS), allopregnanolone and stressful stimuli (AS) and allopregnanolone alone (A). Significance of differences: ${ }^{*} P<0.05$, $\star \star \star P<0.001$

concentration in stressed sheep persisted for $3 \mathrm{~h}(P<0.01-$ $P<0.001$ up to the sixth perfusate) of the collecting period compared to controls. The CRH concentration in the AS group was also higher $(P<0.001)$ than in the $\mathrm{C}$ group: from $P<0.05$ to $P<0.001$ up to the fourth perfusate. There was, however, a decrease $(P<0.05)$ in mean $\mathrm{CRH}$ concentration in the AS group compared to the CS group: the highest difference $(P<0.05)$ was noted in the sixth perfusate. Interestingly, the second rise in $\mathrm{CRH}$ concentration in the AS group was observed in the seventh perfusate $(P<0.05$, compared to controls). In the A group, perfusate CRH concentration was similar to controls, whereas it was less $(P<0.001)$ compared to the concentrations in the CS and AS groups.

Due to the characteristics of hormone response to acute stress (long-term irregular surges with high amplitudes), plasma concentrations of ACTH and cortisol were compared among groups in 1-h periods, without

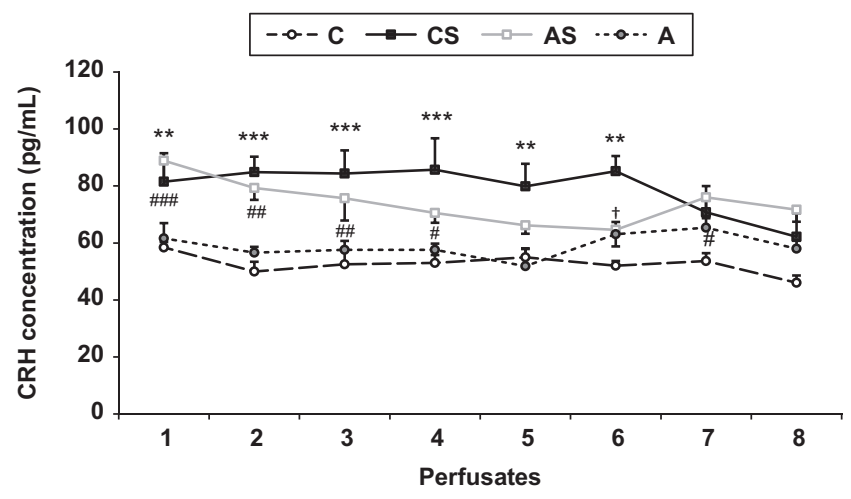

Figure 4

Corticotropin-releasing hormone (CRH) concentrations (mean \pm S.E.M.) in the consecutive perfusates (eight perfusates) over a period of collection from 10:00 to 14:00 (every $30 \mathrm{~min}$ ) in sheep treated with: vehicle (C), vehicle and stressful stimuli (CS), allopregnanolone and stressful stimuli (AS) and allopregnanolone alone (A). Significance of differences: $\star * P<0.01$, and $* * * P<0.001$ CS group vs $C$ group; $\# P<0.05$, \#\#P<0.01, and $\# \# P<0.001$ AS group vs $C$ group; ${ }^{\dagger} P<0.05$ AS group vs CS group. 
calculating the frequency and amplitude of the pulses. The comparisons are depicted in Figs 5 and 6 respectively. There were increases in both plasma ACTH $(P<0.001)$ and cortisol $(P<0.05-P<0.001)$ concentrations in the CS group, which persisted until the end of the experiment in comparison with the $\mathrm{C}$ group. In the AS group, plasma concentration of ACTH begun to decrease $(P<0.001)$ from the second hour of the experiment onward compared to the CS group. The concentration in the AS group was, however, still higher during the subsequent hours than concentrations noted in the $\mathrm{C}$ group $(P<0.001$ in the 2nd, $P<0.01$ in the 3 rd, and $P<0.05$ in the 4 th hour). The mean plasma concentration of cortisol in the AS group decreased $(P<0.05)$ during the first hour of the experiment compared to the CS group, remaining at the same level as in controls to the end of the experiment $(P<0.05-P<0.001$ vs CS group). AL alone had no effect on plasma ACTH concentration at any time of the treatment compared to controls. In the case of cortisol, the only decrease $(P<0.001)$ in plasma concentration occurred in the first hour of the AL treatment in comparison to the control group.

\section{Discussion}

The results of the present study showed several significant changes in the activity of the HPA axis in sheep exposed to acute stressful stimuli. The principal finding of this study, however, was that allopregnanolone, functioning centrally, suppressed the expression of the majority of stress response events. This indicated the important

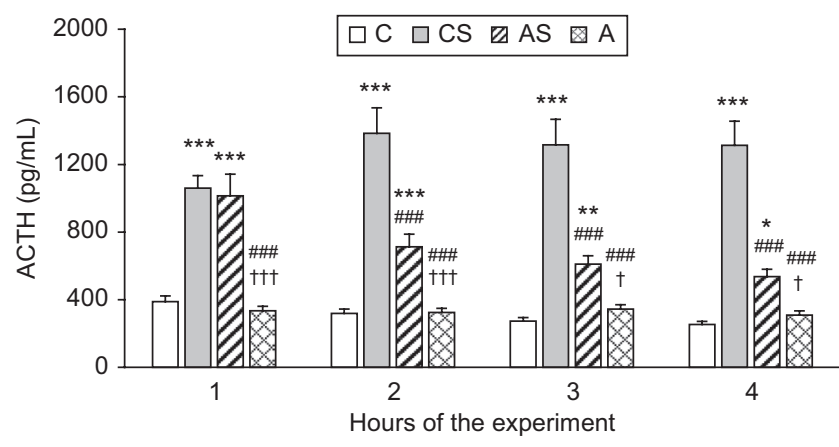

\section{Figure 5}

Adrenocorticotropic hormone (ACTH) concentrations (mean \pm S.E.M.) in 1-h periods in sheep treated with vehicle (C), vehicle and stressful stimuli (CS), allopregnanolone and stressful stimuli (AS) and allopregnanolone alone (A). Significance of differences: $* P<0.05, * * P<0.01$, and $* * * P<0.001$ treatments groups vs $C$ group; \#\# $P<0.001$ treatment groups vs CS group; ${ }^{\dagger} P<0.05$, and ${ }^{\dagger \dagger t} P<0.001$ A group vs AS group.

(C) 2020 Society for Endocrinology Published by Bioscientifica Ltd. Printed in Great Britain

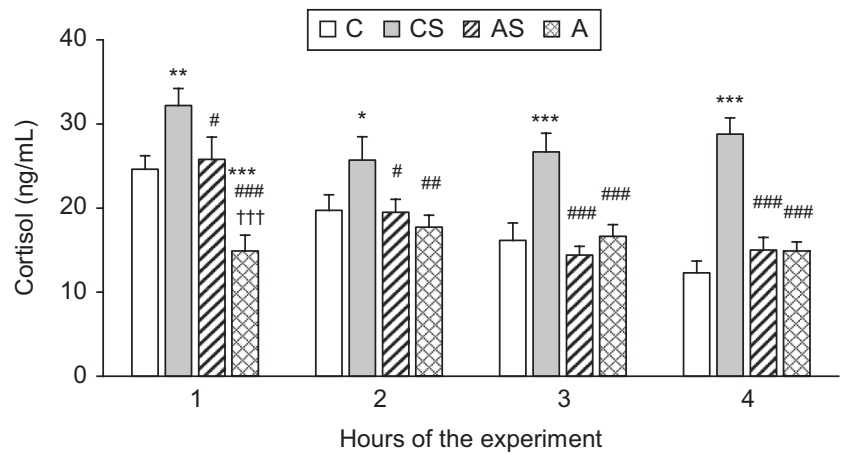

Figure 6

Cortisol concentrations (mean \pm S.E.M.) in 1-h periods in sheep treated with: vehicle (C), vehicle and stressful stimuli (CS), allopregnanolone and stressful stimuli (AS) and allopregnanolone alone (A). Significance of differences: $* P<0.05, * * P<0.01$, and $* \star \star * P<0.001$ treatment groups vs $C$ group; $\# P<0.05$, $\# P<0.01$, and $\# \# P<0.001$ treatment groups vs CS group; ${ }^{\mathrm{tt} P} P<0.001$ A group vs AS group.

protective role of this neurosteroid in the reaction to acute stressors in ruminants.

The results of previous studies indicated that isolation from the flock is a strong stressful stimulus for sheep causing numerous expressive neurosecretory and hormonal changes at the level of the CNS and peripheral blood respectively (Hasiec et al. 2014). In this study, the isolation stress was further enhanced by partial restriction of movement to prevent the animal escaping from the experimental cage. In response to these stimuli, a marked increase in CRH neuron activity in the PVN was observed, expressed by an increase in the abundance of CRH and AVP gene transcripts, and CRH release into the extracellular spaces of the IN/ME. This brain region is rich in nerve terminals, where numerous hypothalamic neurotransmitters and neuropeptides are released into the hypophyseal portal system affecting the secretory activity of the AP. According to Hewitt et al. (2009), acute stress causes alterations in chloride homeostasis within PVN, which releases the HPA axis from GABAergic inhibition, initiating the neuroendocrine stress response. The timeconcentration profile of $\mathrm{CRH}$ in stressed sheep, based on the averaged concentrations of $\mathrm{CRH}$ in individual perfusates, indicated that the releasing activity of CRH neurons persisted for several hours during the stimulation period. The consequence of stress-induced activity of CRH neurons was a significant ACTH surge from the AP, lasting to the end of the experiment. The results of studies on rats and humans indicated that $\mathrm{CRH}$ is a more potent ACTH secretagogue than AVP, but that the latter is essential for a full ACTH response when subjects are challenged by a variety of stressors (Roper et al. 2011). It is suggested that the interaction between the signaling pathways of 
these two neuropeptides causes a variety of biochemical alterations within the corticotrophs, which are in turn responsible for the synergistic effect on ACTH (Liu et al. 1990). In parallel with the secretory response of AP corticotrophs, there was a marked and long-lasting rise in plasma cortisol concentration. Considering the role of GC negative feedback (Keller-Wood \& Dallman 1984), cortisol may have initiated the inhibition of the stress response, which was reflected by decreased CRH concentration in perfusates during the fourth hour of collection.

The pattern of the neuroendocrine stress reaction is complemented in the present study by data that show changes in the abundance of CRH and AVP receptors mRNA, as well as POMC mRNA in the AP of stressed animals. Both CRHR1 and AVPRV1b are co-expressed in corticotrophs and participate in the HPA axis activation in response to different stressful stimuli (Nikodemova et al. 2002, Jasnic et al. 2013) forming homo- and heterodimers in a ligand-independent manner (Young et al. 2007). In the present study there was a decrease in the relative abundance of CRHR1 transcripts in response to acute stressors. This finding is in agreement with the results of earlier studies on rodents, which also indicated that CRH receptors mRNA level in the AP is affected by changing concentrations of $\mathrm{CRH}$ and GC during alterations of HPA axis activity (Aguilera 1998, Young et al. 2007, Greetfeld et al. 2009). It was shown that both $\mathrm{CRH}$ and GC may downregulate the CRH receptors in the pituitary corticotrophs implicating these receptors in the mechanism of stress response regulation (Hauger et al. 1987, Kasagi et al. 2002, Klenerova et al. 2018). The number of active CRH receptors in the cell membrane, however, does not depend on the levels of mRNA and full ACTH responses can be achieved with partial receptor occupancy (Aguilera 1994, Nikodemova et al. 2002). Moreover, post-receptor events probably contribute to sustained ACTH responses in the presence of reduced CRH binding (Aguilera et al. 2004). In the present study, an interesting relationship can also be observed in response to acute stress: strong CRH mRNA expression/weak CRHR1mRNA expression vs. weak AVP mRNA expression/ strong AVPV1b mRNA expression. Thus, an increase in the abundance of AVPRV1b mRNA could compensate for the smaller amount of CRHR1 mRNA to enhance the secretion of ACTH. It was possible that sustained high plasma ACTH concentrations, followed by increased cortisol secretion, resulted from the activation of different signal transduction pathways and/or post-transcriptional processing of CRHR1 and AVPRV1b mRNA. This is further supported by the increased abundance of POMC mRNA in the AP of stressed animals. Transcriptional stimulation of the pituitary POMC gene has been observed previously in rats after a single restraint challenge (Autelitano 1998). Due to the multiple role of the POMC gene transcript, its protein products may contribute either to the maintenance of the stress response (ACTH) or to its completion ( $\beta$-endorphin).

In general, neurosteroids are synthesized in the brain and modulate neuronal excitability by rapid non-genomic actions (Baulieu 1991, Paul \& Purdy 1992, Zheng 2009). In particular, AL was shown to be a highly selective modulator of $\mathrm{GABA}_{\mathrm{A}}$ receptor-mediated neurotransmission (Gunn et al. 2011, Sarkar et al. 2011). Previous studies on rats and mice indicated that activation of the HPA axis by acute stressors, such as swim stress, $\mathrm{CO}_{2}$ inhalation or LPS treatment is associated with increases in neuroactive steroid concentrations in plasma and the brain (Purdy et al. 1991, Barbaccia et al. 1994, Billiards et al. 2002, Sze et al. 2018). Purdy et al. (1991) showed that in the rat brain (cerebral cortex and hypothalamus) AL concentration increased for an hour after initiation of stress, prior to peaking in the plasma. Moreover, stress had a greater impact on central AL concentrations in females, than in males (Sze et al. 2018). The results of other studies confirmed that stress could regulate neurosteroid biosynthesis via the hormones CRH and ACTH (Torres et al. 2001). It is thought that the concentration of neurosteroids increases to have, in turn, stress-protective effects (Purdy et al. 1991, Gunn et al. 2011). In the present study, a reduction of the neuroendocrine stress-response of the HPA axis following AL treatment was observed at all tested compartments: central, pituitary and consistently peripheral. Although the difference in mean CRH concentrations between the CS and AS groups reached a significance at only $P<0.05$, the time-concentration profile according to the individual perfusates clearly showed a lowering $\mathrm{CRH}$ concentration during AL treatment. The reduction of $\mathrm{CRH}$ response to stress in the AS group was continued for $3 \mathrm{~h}$, after which the concentration of $\mathrm{CRH}$ increased again. Interestingly, the second increase in CRH concentration in the AS group occurred at the same time as a decrease in CRH concentration in the CS group. These events are difficult to explain, but they may indicate changes in stimulatory or inhibitory neural signaling in response to prolonged stressful stimuli and/or AL treatment. For example, the changes in $\mathrm{GABA}_{\mathrm{A}}$ receptors sensitization and/or plasticity in CRH neurons could be taken under consideration (Miklos \& Kovacs 2002, Kim et al. 2019). https://joe.bioscientifica.com

https://doi.org/10.1530/JOE-19-0376 (c) 2020 Society for Endocrinology Published by Bioscientifica Ltd. Printed in Great Britain 
Moreover, AL reduced the abundance of CRH and AVP mRNA in the PVN. The difference in the inhibition of the stress-induced expression of $C R H$ and $A V P$ genes in the PVN may confirm the differential role of both neuropeptides in stimulating ACTH secretion, especially in response to acute stressors (Engler et al. 1989, Familari et al. 1989, Roper et al. 2011). The potency of CRH mRNA expression, induced by stress, despite the inhibitory action of $\mathrm{AL}$, was much greater in the AS group than for AVP mRNA. This may indicate a dominant role for $\mathrm{CRH}$ at least in initiating a stress response in sheep. Furthermore, a decrease in CRH mRNA expression following administration of $\mathrm{AL}$ alone may suggest a preventive silencing effect on HPA axis activity at the molecular level. Budziszewska et al. (2010) found that AL inhibited CRH gene promoter activity in the differentiated Neuro-2A cells and suggested that the inhibition of $C R H$ gene transcription may be a molecular mechanism responsible, at least partly, for its stress-protective effects. Similarly, such a situation may be related to the reduced expression of CRH and AVP receptors mRNA, as well as POMC mRNA in the AP, since some data point also to the involvement of other possible AL targets, such as intracellular nuclear receptors, protein kinases and microtubule-associated protein (PlassartSchiess \& Baulieu 2001).

Another interesting observation in the present study concerns the changes in the concentrations of ACTH and cortisol in peripheral circulation in the AS group, which indicate faster return of adrenal cortisol to control levels. This may not be accidental, because a peripheral mechanism that prevents excessive supply of GC, including function of adrenal and/or ovary originated AL (Corpechot et al. 1993), cannot be ruled out. It was possible that increased secretion of progesterone in the luteal phase of the estrous cycle promotes peripheral production of allopregnanolone. Furthermore, there were initial increases in plasma concentrations of ACTH and cortisol observed in the control group caused probably by the handling and insertion of cannulas into the CNS. On the contrary, in sheep from group A, a clear anti-stress effect of AL was observed, at least in the case of cortisol secretion, during the first hour of the infusion.

The suppressive effects of neurosteroids on neuroendocrine responses to stress were extensively studied in pregnant females, fetuses and newborns (Brunton \& Russell 2011, Brunton 2015, Hirst et al. 2016). The results of the present study form part of research into the preventive and anti-stress action of $\mathrm{AL}$ and simultaneously show that adult sheep are a convenient model for stress research at the CNS level.
In conclusion, allopregnanolone may function centrally as a suppressor of HPA axis activity in adult stressed sheep.

\section{Declaration of interest}

The authors declare that there is no conflict of interest that could be perceived as prejudicing the impartiality of the research reported.

\section{Funding}

The research was supported by the National Science Center, Poland (grant No. 2015/19/B/NZ9/03706.

\section{Data statement}

The datasets analyzed during the current study are available from the corresponding author, given appropriate justification.

\section{Author contribution statement}

T M developed the original concept and experimental design. T M, P M, E M and $\mathrm{A} M$ performed the experiment and laboratory analyses. T M and P M analyzed the data, edited and wrote the manuscript. All authors approved the final version.

\section{Acknowledgements}

The authors thank veterinary surgeons J Rutkowski and K RoszkowiczOstrowska for performing brain surgery, and also W Mrozek and R Druchniak for animal care.

\section{References}

Aguilera G 1994 Regulation of pituitary ACTH secretion during chronic stress. Frontiers in Neuroendocrinology 15 321-350. (https://doi. org/10.1006/frne.1994.1013)

Aguilera G 1998 Corticotropin releasing hormone, receptor regulation and the stress response. Trends in Endocrinology and Metabolism 9 329-336. (https://doi.org/10.1016/S1043-2760(98)00079-4)

Aguilera G, Nikodemova M, Wynn PC \& Catt KJ 2004 Corticotropin releasing hormone receptors: two decades later. Peptides 25 319-329. (https://doi.org/10.1016/j.peptides.2004.02.002)

Autelitano DJ 1998 Stress-induced stimulation of pituitary POMC gene expression is associated with activation of transcription factor AP-1 in hypothalamus and pituitary. Brain Research Bulletin 45 75-82. (https:// doi.org/10.1016/s0361-9230(97)00303-1)

Barbaccia ML, Roscetti G, Trabucchi M, Cuccheddu T, Concas A \& Biggio G 1994 Neurosteroids in the brain of handling-habituated and naive rats: effect of $\mathrm{CO} 2$ inhalation. European Journal of Pharmacology 261 317-320. (https://doi.org/10.1016/0014-2999(94)90123-6)

Baulieu EE 1991 Neurosteroids: a new function in the brain. Biology of the Cell 71 3-10. (https://doi.org/10.1016/0248-4900(91)90045-o)

Billiards SS, Walker DW, Canny BJ \& Hirst JJ 2002 Endotoxin increases sleep and brain allopregnanolone concentrations in newborn lambs. Pediatric Research 52 892-899. (https://doi.org/10.1203/00006450200212000-00014) 
Boudaba C, Szabo K \& Tasker JG 1996 Physiological mapping of local inhibitory inputs to the hypothalamic paraventricular nucleus. Journal of Neuroscience 16 7151-7160. (https://doi.org/10.1523/ JNEUROSCI.16-22-07151.1996)

Brunton PJ 2015 Programming the brain and behaviour by early-life stress: a focus on neuroactive steroids. Journal of Neuroendocrinology $\mathbf{2 7}$ 468-480. (https://doi.org/10.1111/jne.12265)

Brunton PJ 2016 Neuroactive steroids and stress axis regulation: pregnancy and beyond. Journal of Steroid Biochemistry and Molecular Biology 160 160-168. (https://doi.org/10.1016/j.jsbmb.2015.08.003)

Brunton PJ \& Russell JA 2011 Allopregnanolone and suppressed hypothalamo-pituitary-adrenal axis stress responses in late pregnancy in the rat. Stress 14 6-12. (https://doi.org/10.3109/10253890.2010.482628)

Brunton PJ, McKay AJ, Ochedalski T, Piastowska A, Rebas E, Lachowicz A \& Russell JA 2009 Central opioid inhibition of neuroendocrine stress responses in pregnancy in the rat is induced by the neurosteroid allopregnanolone. Journal of Neuroscience 29 6449-6460. (https://doi. org/10.1523/JNEUROSCI.0708-09.2009)

Budziszewska B, Zajac A, Basta-Kaim A, Leśkiewicz M, Steczkowska M, Lasoń W \& Kuciński M 2010 Effects of neurosteroids on the human corticotropin-releasing hormone gene. Pharmacological Reports 62 1030-1040. (https://doi.org/10.1016/S1734-1140(10)70365-0)

Ciechanowska M, Lapot M, Malewski T, Mateusiak K, Misztal T \& Przekop F 2009 Effects of $\mathrm{GABA}_{\mathrm{A}}$ receptor modulation on the expression of $G n R H$ gene and $G n R H$ receptor $(G n R H-R)$ gene in the hypothalamus and $G n R H-R$ gene in the anterior pituitary gland of follicular-phase ewes. Animal Reproduction Science $111235-248$ (https://doi.org/10.1016/j.anireprosci.2008.03.006)

Colmers PLW \& Bains JS 2018 Balancing tonic and phasic inhibition in hypothalamic corticotropin-releasing hormone neurons. Journal of Physiology 596 1919-1929. (https://doi.org/10.1113/JP275588)

Corpechot C, Young J, Calvel M, Wehrey C, Veltz JN, Touyer G, Mouren M, Prasad VV, Banner C \& Sjövall J 1993 Neurosteroid: $3 \alpha$-hydroxy- $5 \alpha$-pregnan-20-one and its precursor in the brain, plasma, and steroidogenic glands of male and female rats. Endocrinology 133 1003-1009. (https://doi.org/10.1210/endo.133.3.8365352)

Decavel C \& Van den Pol AN 1990 GABA: a dominant neurotransmitter in the hypothalamus. Journal of Comparative Neurology 3021019 1037. (https://doi.org/10.1002/cne.903020423)

Engler D, Pham T, Fullerton MJ, Ooi G, Funder JW \& Clarke IJ 1989 Studies of the secretion of corticotropin-releasing factor and arginine vasopressin into the hypophysial-portal circulation of the conscious sheep. I. Effect of an audiovisual stimulus and insulininduced hypoglycemia. Neuroendocrinology 49 367-381. (https://doi. org/10.1159/000125141)

Familari M, Smith AI, Smith R \& Funder JW 1989 Arginine vasopressin is a much more potent stimulus to ACTH release from ovine anterior pituitary cells than ovine corticotropin releasing factor. 1. In vitro studies. Neuroendocrinology 50 152-157. (https://doi. org/10.1159/000125214)

Greetfeld M, Schmidt MV, Ganea K, Sterlemann V, Liebl C \& Müller MB 2009 A single episode of restraint stress regulates central corticotrophin-releasing hormone receptor expression and binding in specific areas of the mouse brain. Journal of Neuroendocrinology $\mathbf{2 1}$ 473-480. (https://doi.org/10.1111/j.1365-2826.2009.01865.x)

Gunn BG, Brown AR, Lambert JJ \& Belelli D 2011 Neurosteroids and GABA(A) receptor interactions: a focus on stress. Frontiers in Neuroscience 5 131. (https://doi.org/10.3389/fnins.2011.00131)

Gunn BG, Cunningham L, Cooper MA, Corteen NL, Seifi M, Swinny JD, Lambert JJ \& Belelli D 2013 Dysfunctional astrocytic and synaptic regulation of hypothalamic glutamatergic transmission in a mouse model of early-life adversity: relevance to neurosteroids and programming of the stress response. Journal of Neuroscience $\mathbf{3 3}$ 19534-19554. (https://doi.org/10.1523/JNEUROSCI.1337-13.2013)

Hasiec M \& Misztal T 2018 Adaptive modifications of maternal hypothalamic-pituitary-adrenal axis activity during lactation and salsolinol as a new player in this phenomenon. International Journal of Endocrinology 2018 Article ID 3786038. (https://doi. org/10.1155/2018/3786038)

Hasiec M, Tomaszewska-Zaremba D \& Misztal T 2014 Suckling and salsolinol attenuate responsiveness of the hypothalamic-pituitaryadrenal axis to stress: focus on catecholamines, corticotrophinreleasing hormone, adrenocorticotrophic hormone, cortisol and prolactin secretion in lactating sheep. Journal of Neuroendocrinology 26 844-852. (https://doi.org/10.1111/jne.12222)

Hauger RL, Millan MA, Catt KJ \& Aguilera G 1987 Differential regulation of brain and pituitary corticotropin releasing factor receptors by corticosterone. Endocrinology 120 1527-1533. (https://doi. org/10.1210/endo-120-4-1527)

Herman JP, Mueller NK \& Figueiredo H 2004 Role of GABA and glutamate circuitry in hypothalamo-pituitary-adrenocortical stress integration. Annals of the New York Academy of Sciences 1018 35-45. (https://doi. org/10.1196/annals.1296.004)

Hewitt SA, Wamsteeker JI, Kurz EU \& Bains JS 2009 Altered chloride homeostasis removes synaptic inhibitory constraint of the stress axis. Nature Neuroscience 12 438-443. (https://doi.org/10.1038/nn.2274)

Hirst JJ, Cumberland AL, Shaw JC, Bennett GA, Kelleher MA, Walker DW \& Palliser HK 2016 Loss of neurosteroid-mediated protection following stress during fetal life. Journal of Steroid Biochemistry and Molecular Biology 160 181-188. (https://doi.org/10.1016/j. jsbmb.2015.09.012)

Jasnic N, Djordjevic J, Vujovic P, Lakic I, Djurasevic S \& Cvijic G 2013 The effect of vasopressin $1 \mathrm{~b}$ receptor $(\mathrm{V} 1 \mathrm{bR})$ blockade on HPA axis activity in rats exposed to acute heat stress. Journal of Experimental Biology 216 2302-2307. (https://doi.org/10.1242/jeb.082842)

Kasagi Y, Horiba N, Sakai K, Fukuda Y \& Suda T 2002 Involvement of cAMP-response element binding protein in corticotropin-releasing factor (CRF)-induced down-regulation of CRF receptor 1 gene expression in rat anterior pituitary cells. Journal of Neuroendocrinology 14 587-592. (https://doi.org/10.1046/j.1365-2826.2002.00816.x)

Keller-Wood ME \& Dallman MF 1984 Corticosteroid inhibition of ACTH secretion. Endocrine Reviews 5 1-24. (https://doi.org/10.1210/edrv-51-1)

Kim YB, Colwell CS \& Kim YI 2019 Long-term ionic plasticity of GABAergic signalling in the hypothalamus. Journal of Neuroendocrinology 31 e12753. (https://doi.org/10.1111/jne.12753)

Klenerova V, Kvetnansky R \& Hynie S 2018 The effect of acute and repeated stress on CRH-R1 and CRH-R2 mRNA expression in pituitaries of wild type and CRH knockout mice. Cellular and Molecular Neurobiology 38 163-169. (https://doi.org/10.1007/s10571017-0556-3)

Kokot F \& Stupnicki R 1985 Radioimmunological and radiocompetitive methods in clinical use [in Polish]. Warsaw, Poland: PZWL.

Liu JP, Robinson PJ, Funder JW \& Engler D 1990 The biosynthesis and secretion of adrenocorticotropin by the ovine anterior pituitary is predominantly regulated by arginine vasopressin (AVP). Evidence that protein kinase $\mathrm{C}$ mediates the action of AVP. Journal of Biological Chemistry 265 14136-14142.

McEwen BS 2007 Physiology and neurobiology of stress and adaptation: central role of the brain. Physiological Reviews 87 873-904. (https:// doi.org/10.1152/physrev.00041.2006)

Melcangi RC, Celotti F, Castano P \& Martini L 1993 Differential localization of the 5 alpha-reductase and the 3 alpha-hydroxysteroid dehydrogenase in neuronal and glial cultures. Endocrinology 132 1252-1259. (https://doi.org/10.1210/endo.132.3.8440186)

Miklos IH \& Kovacs KJ 2002 GABAergic innervation of corticotropinreleasing hormone (CRH)-secreting parvocellular neurons and its plasticity as demonstrated by quantitative immunoelectron microscopy. Neuroscience 113 581-592. (https://doi.org/10.1016/ s0306-4522(02)00147-1)

Nicol MB, Hirst JJ \& Walker D 1999 Effects of pregnanolone on behavioural parameters and the responses to GABA(A) receptor https://joe.bioscientifica.com

https://doi.org/10.1530/JOE-19-0376 (c) 2020 Society for Endocrinology Published by Bioscientifica Ltd. Printed in Great Britain 
antagonists in the late gestation fetal sheep. Neuropharmacology 38 49-63. (https://doi.org/10.1016/s0028-3908(98)00166-x)

Nikodemova M, Diehl CR \& Aguilera G 2002 Multiple sites of control of type-1 corticotropin releasing hormone receptor levels in the pituitary. Archives of Physiology and Biochemistry 110 123-128. (https:// doi.org/10.1076/apab.110.1.123.901 )

Paul SM \& Purdy RH 1992 Neuroactive steroids. FASEB Journal $62311-$ 2322. (https://doi.org/10.1096/fasebj.6.6.1347506)

Pfaffl MW, Horgan GW \& Dempfle L 2002 Relative expression software tool (REST) for group-wise comparison and statistical analysis of relative expression results in real-time PCR. Nucleic Acids Research 30 e36. (https://doi.org/10.1093/nar/30.9.e36)

Pfaffl MW, Tichopad A, Prgomet C \& Neuvians TP 2004 Determination of stable housekeeping genes, differentially regulated target genes and sample integrity: BestKeeper - Excel-based tool using pairwise correlations. Biotechnology Letters 26 509-515. (https://doi. org/10.1023/B:BILE.0000019559.84305.47)

Plassart-Schiess E \& Baulieu EE 2001 Neurosteroids: recent findings. Brain Research: Brain Research Reviews 37 133-140. (https://doi.org/10.1016/ S0165-0173(01)00113-8)

Purdy RH, Morrow AL, Moore PH \& Paul SM 1991 Stress-induced elevations of gamma-aminobutyric acid type A receptor-active steroids in the rat brain. PNAS $\mathbf{8 8} 4553-4557$. (https://doi. org/10.1073/pnas.88.10.4553)

Roper JA, O'Carroll AM, Young 3rd W \& Lolait SJ 2011 The vasopressin Avpr $1 b$ receptor: molecular and pharmacological studies. Stress $\mathbf{1 4}$ 98-115. (https://doi.org/10.3109/10253890.2010.512376)

Sarkar J, Wakefield S, MacKenzie G, Moss SJ \& Maguire J 2011 Neurosteroidogenesis is required for the physiological response to stress: role of neurosteroid-sensitive GABAA receptors. Journal of Neuroscience 31 18198-18210. (https://doi.org/10.1523/

JNEUROSCI.2560-11.2011)
Strzetelski J 2009 IZ PIB-INRA nutrient requirements for ruminants [in Polish]. Krakow, Poland: Iz PIB Krakow.

Sze Y, Gill AC \& Brunton PJ 2018 Sex-dependent changes in neuroactive steroid concentrations in the rat brain following acute swim stress. Journal of Neuroendocrinology 30 e12644. (https://doi.org/10.1111/ jne.12644)

Torres JM, Ruiz E \& Ortega E 2001 Effects of CRH and ACTH administration on plasma and brain neurosteroid levels. Neurochemical Research 26 555-558. (https://doi. org/10.1023/a:1010925331768)

Traczyk W \& Przekop F 1963 Methods of investigation of the function of the hypothalamus and hypophysis in chronic experiments in sheep [in Polish]. Acta Physiologica Polonica 14 227-236.

Vyas S, Rodrigues AJ, Silva JM, Tronche F, Almeida OFX, Sousa N \& Sotiropoulos I 2016 Chronic stress and glucocorticoids: from neuronal plasticity to neurodegeneration. Neural Plasticity 2016 Article ID 6391686. (https://doi.org/10.1155/2016/6391686)

Welento J, Szteyn S \& Milart Z 1969 Observations on the stereotaxic configuration of the hypothalamus nuclei in the sheep. Anatomischer Anzeiger 124 1-27.

Yawno T, Hirst JJ, Castillo-Melendez M \& Walker DW 2009 Role of neurosteroids in regulating cell death and proliferation in the late gestation fetal brain. Neuroscience 163 838-847. (https://doi. org/10.1016/j.neuroscience.2009.07.009)

Young SF, Griffante C \& Aguilera G 2007 Dimerization between vasopressin $\mathrm{V} 1 \mathrm{~b}$ and corticotropin releasing hormone type 1 receptors. Cellular and Molecular Neurobiology 27 439-461. (https://doi. org/10.1007/s10571-006-9135-8)

Zheng P 2009 Neuroactive steroid regulation of neurotransmitter release in the CNS: action, mechanism and possible significance. Progress in Neurobiology 89 134-152. (https://doi.org/10.1016/j. pneurobio.2009.07.001)

Received in final form 27 September 2019

Accepted 10 October 2019

Accepted Manuscript published online 10 October 2019
(C) 2020 Society for Endocrinology Published by Bioscientifica Ltd.
Printed in Great Britain 